Brit. F. industr Med., 1967, 24, 26

\title{
Prevalence of Chronic Respiratory Disease in a Pulp Mill and a Paper Mill in the United States ${ }^{1}$
}

\author{
B. G. FERRIS, Jr., W. A. BURGESS, and J. WORCESTER \\ From the Division of Environmental Health Sciences and Engineering, and the Department of Biostatistics, \\ Harvard School of Public Health, Boston, Massachusetts 02115
}

A sample of 147 men drawn from the workers in a pulp mill was compared with one of 124 men from a paper mill. The former included those exposed to chlorine and to sulphur dioxide. No significant differences were found in respiratory symptoms or in simple tests of ventilatory function in the two samples, but men working in chlorine had a somewhat poorer respiratory function and more shortness of breath than those working in sulphur dioxide.

The working population of both mills together had a lower prevalence of respiratory disease than that of the male population of Berlin, N.H., previously studied, suggesting that working populations may not be representative of the general population. Further, a low prevalence of disease in a working population exposed to pollutants may not indicate their 'safety' in general populations.

In a previous study of the prevalence of chronic respiratory disease in Berlin, N.H. (Ferris and Anderson, 1962) we had hoped to obtain a large number of men who worked in the local pulp and paper plants. From such a sample we planned to determine whether the exposures at work in the mill had any influence on the prevalence of chronic respiratory disease. The number of workers in the sample was too small to demonstrate any significant influence of exposure at work. We therefore approached the company for permission to draw a large sample of men who worked in areas where there was a possible significant exposure to noxious gases $\left(\mathrm{SO}_{2}, \mathrm{Cl}_{2}\right.$, or $\left.\mathrm{ClO}_{2}\right)$ and another sample from the paper mill where there was no such exposure. Permission was granted and two samples were drawn.

\section{Plant Processes}

The pulp mill complex contained two chemical pulp mills - one a Kraft mill and the second a sulphite mill and, in addition, a chlorine plant. Abbreviated process flow sheets for the two mills are shown in Figures I and 2. In both mills wood chips are introduced into large digesters or batch pressure cookers.

\footnotetext{
${ }^{1}$ This study was supported in part by U.S. Public Health Service Grant OH-67.

Received for publication May 5, 1966.
}

Cooking liquor is added and the batch is 'cooked' under raised temperature and pressure. The cooking liquor in the Kraft process is sodium sulphide, hydroxide, sulphite, and carbonate. In the sulphite phase the digester load is dropped or 'blown' into pits. The cooking liquor is drained for recovery and re-use and the pulp undergoes final processing. The two processes result in exposures of personnel to sulphur dioxide, hydrogen sulphide, and some organic sulphides including mercaptans.

In the final processing, the pulp is washed and bleached. The first stage of bleaching is carried out with chlorine or chlorine dioxide. This plant manufactured its own chlorine and chlorine dioxide.

Records of each man's exposure to air contaminants in the pulp, paper, and chlorine plants during his total working history would be invaluable. Unfortunately, this information is rarely available in industry due to frequent changes in work assignments within the plant, changes in materials and processes over the years as pulp technology develops, limited air sampling data, and, lastly, the difficulty in assessing short periods of high concentration which occasionally occur due to failure of equipment.

\section{Methods}

Population Sampling The samples consisted of 147 men from the pulp mill and 124 men from the paper mill. The sample from the pulp mill con- 


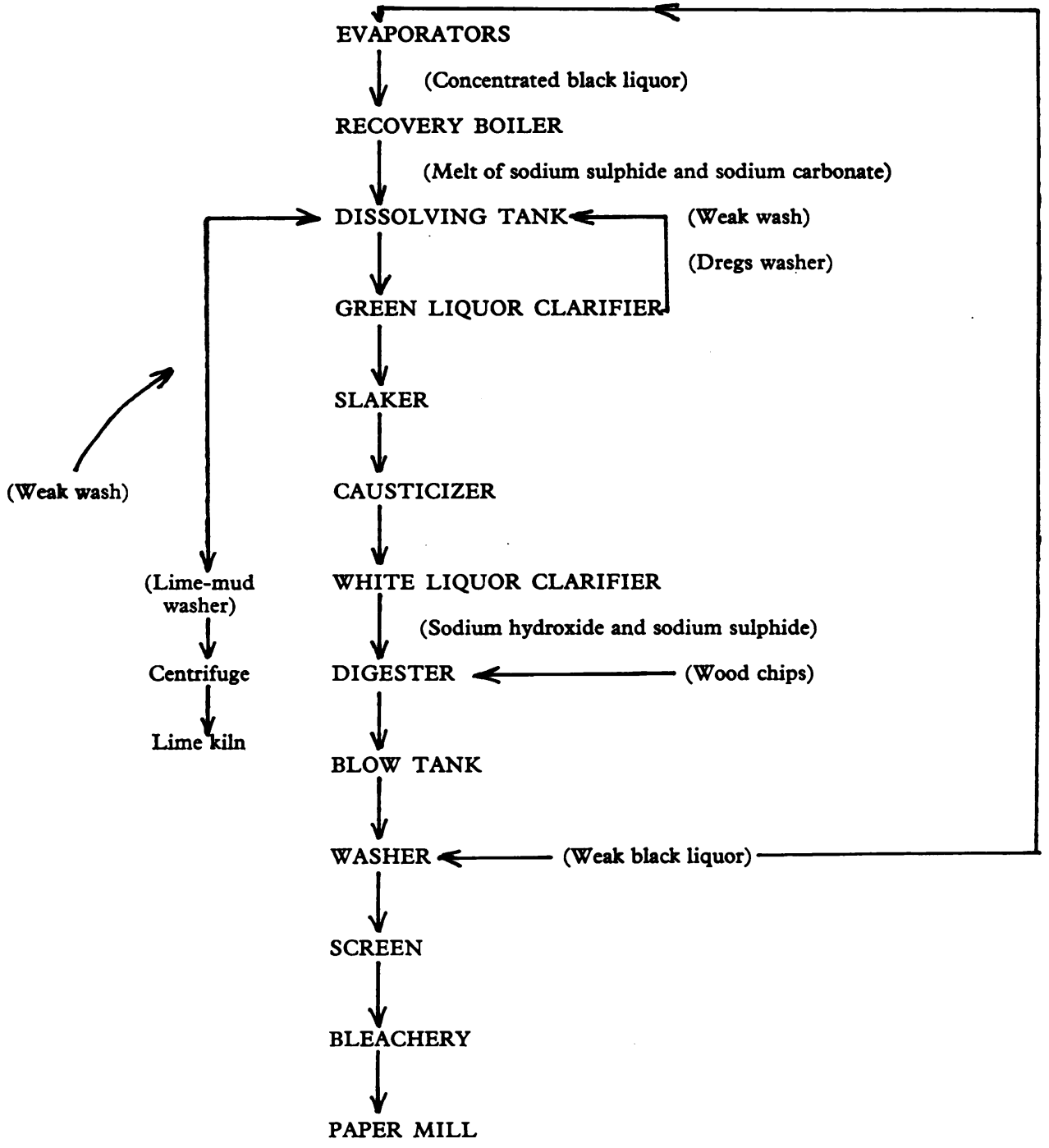

FIG. I. Kraft flow sheet.

sisted of all the men who were working in the chlorine plant, sulphite mill, Kraft plant, and $\mathrm{ClO}_{2}$ plant on October 17, 1962. The sample from the paper mill included the men on the paper machines and the maintenance men (pipers and millwrights). Between the time of drawing and surveying the sample the sulphite plant had shut down. A number of men were released, some were transferred to other departments, and others had retired. When we surveyed the sample we included those who had retired and those who had been released and who still worked in the Berlin area.
The survey was conducted in December 1963/ January 1964 at the medical dispensaries of the two plants. Those men who were unable to attend at the plant were visited at home.

The survey included the taking of an occupational history and the use of a standard respiratory questionnaire similar to that developed by the British Medical Research Council. A life-time smoking history was obtained as the last item on the questionnaire.

Simple tests of pulmonary function were done with the subject standing and without wearing a 


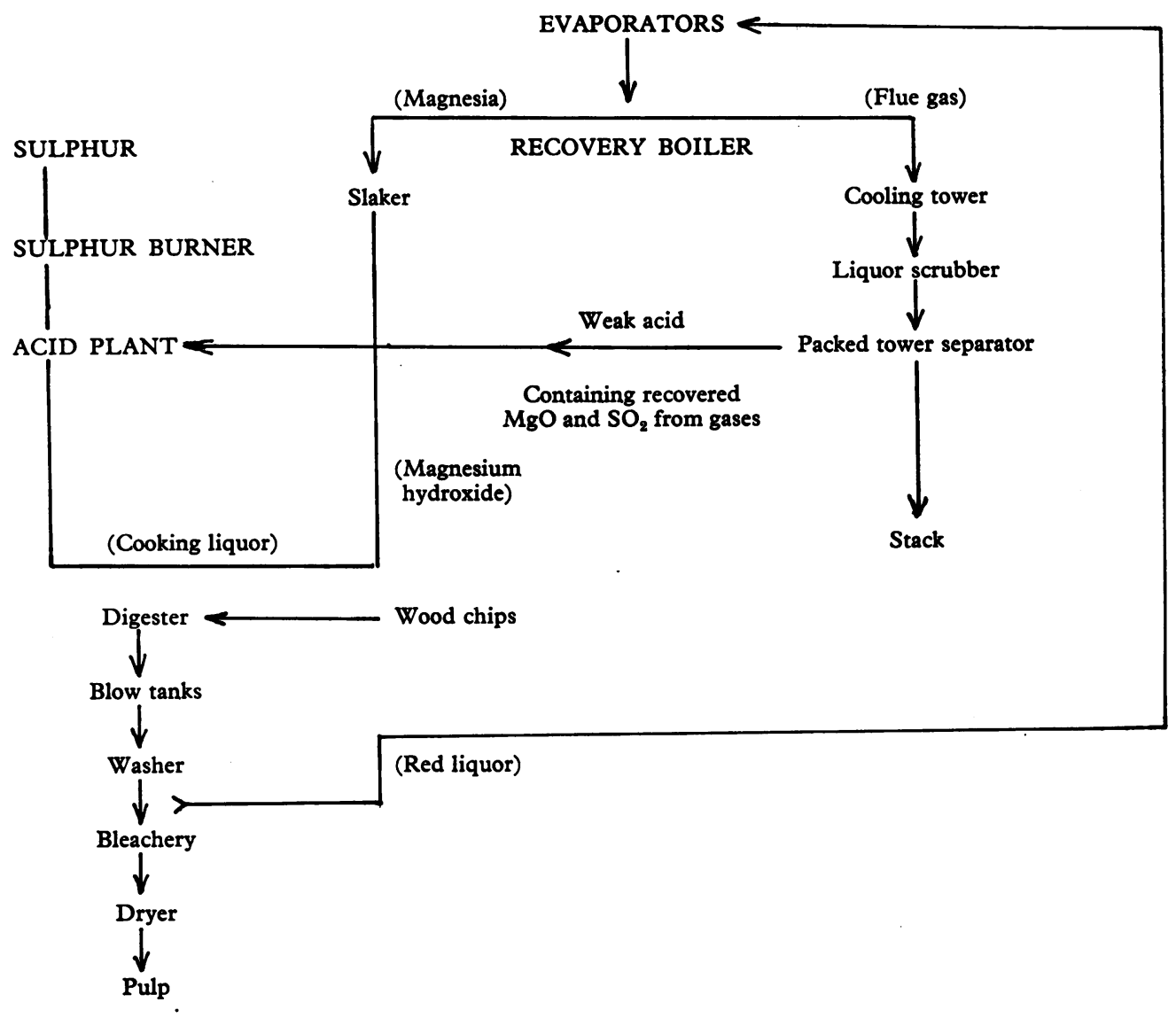

FIG. 2. Sulphite flow sheet.

nose clip. Five forced vital capacity measurements (F.V.C.) were determined by a recording spirometer ${ }^{1}$. The mean F.V.C. and the forced expiratory volume in the first second (F.E.V.1.0) were determined from the last three tracings. Inaccuracies due to variations in the starting of a rapid expiration were reduced by extrapolating the steepest part of the curve back to zero volume. Time was measured from this intercept (American College of Chest Physicians, 1963). All volumes were corrected to body temperature, normal pressure, and water vapour saturation. In addition, five trials were done on the Wright peak flowmeter. An average of the last three results was used.

Standing height in stockinged feet was measured against a tape on a wall with the use of a right-angle. Measurements were made to the nearest 0.5 inch. Age was taken as that on the most recent birthday.

1 Collins, Stead-Wells model.
The presence of respiratory disease was defined on the basis of positive responses to specific questions as follows:-

(I) Chronic bronchitis, if the respondent admitted to bringing up phlegm from the chest on at least four days a week for three months of the year for the past three years;

(2) Asthma, if the respondent had a history of bronchial asthma that had been diagnosed by a physician and that was still present;

(3) Obstructive lung disease, if the respondent admitted to a history of wheezing or 'whistling' in the chest on most days or nights, and/or shortness of breath, not due to neuromuscular disability, that caused him to stop for breath when walking at his own pace on the level and/or a mean F.E.V.1.0 less than $60 \%$ of the forced vital capacity.

Air Sampling and Analyses In February 1963, air sampling for sulphur dioxide in air was 
conducted with a midget impinger using an absorption solution consisting of $4 \mathrm{ml}$. of $0.01 \mathrm{~N}$ iodine and $6 \mathrm{ml}$. of $50 \%$ potassium iodide solution. The samples were normally collected in occupied work spaces over a period of 15 minutes with the sampling rate maintained at a fixed rate of $0.1 \mathrm{ft}^{3} /$ minute. The collection efficiency of this sampler for sulphur dioxide is approximately $95 \%$. The samples were titrated with standardized $0.0 \mathrm{r} \mathrm{N}$ sodium thiosulphate and the average concentration of sulphur dioxide was calculated, based on the titration, sampling rate, and sampling time.

In certain sampling locations within the plant the concentration of sulphur dioxide was sufficient to allow direct air titration. In these cases the sampling was conducted until the absorption solution lost its yellow colour. The sampling was then stopped and the total sampling time noted. The air concentration of sulphur dioxide was calculated from the milli-equivalents of iodine originally added to the impinger, the sampling rate, and the sampling time.

Continuous sampling for sulphur dioxide over an extended period of time, as described above, was complemented by sampling with direct-reading indicating tubes for sulphur dioxide. ${ }^{1}$ In this detection system a measured volume of air is passed through an indicating tube filled with inert granules impregnated with a reactive chemical. A stain is

${ }^{1} \mathrm{SO}_{2}$ detector tube '0.0I' and Draeger model I9/3I gas detector (Draegerwerk, Lübeck, Germany). produced, the length of which is proportional to the concentration of sulphur dioxide in the air. The lowest sensitivity of this tube is approximately 4 p.p.m. Air sampling with this device can be carried out in less than a minute, thereby permitting evaluation of 'instantaneous' concentrations of sulphur dioxide in air.

Similar detector tubes were used for 'instantaneous' sampling for hydrogen sulphide and for chlorine $^{2}$ in the 1963 survey. The lowest level of sensitivity of the hydrogen sulphide tube was 5 p.p.m.; that of the chlorine tube was $r \cdot 0$ p.p.m.

\section{Results}

The composition of the population as drawn on October 17, 1962 and its later disposition are presented in Table I. As noted above, most of those whose employment had been terminated were from the paper mill and all were in the younger age groups. It is of interest that all the five deaths occurred in men from the paper mill. Four persons; or $1.5 \%$ of those available, refused to co-operate.

Limited data on the exposure to sulphur dioxide of pulp mill workers have been presented by previous investigators (Skalpe, 1964; Anderson, I950; Kehoe, Machle, Kitzmiller, and LeBlanc,

${ }^{2}$ Kitagawa hydrogen sulphide low range detector tubes and chlorine detector tubes (Union Industrial Equipment Co., Fall River, Mass.).

TABLE I

Composition and Disposition of SAMPLE

\begin{tabular}{|c|c|c|c|c|c|c|c|c|c|c|c|c|c|}
\hline \multirow[b]{2}{*}{ Age group (years) $\ldots \quad \ldots$} & \multicolumn{6}{|c|}{ Pulp Mill } & \multicolumn{7}{|c|}{ Paper Mill } \\
\hline & $25-34$ & $35-44$ & $45-54$ & $55-64$ & $65-74$ & Total & $20-24$ & $25-34$ & $35-44$ & $45-54$ & $55-64$ & $65-74$ & Total \\
\hline $\begin{array}{cccc}\text { Sample } & \text { drawn } & \text { 17 } & \text { October } \\
1962 & \ldots & \ldots & \ldots\end{array}$ & I4 & 42 & 39 & 54 & ro & 159 & 2 & 54 & 37 & 37 & 37 & 3 & 170 \\
\hline $\begin{array}{l}\text { Removed from sample- } \\
\text { worked less than one year.. }\end{array}$ & 一 & 一 & - & - & 一 & o & 2 & $\mathbf{I}$ & 一 & 一 & - & - & 3 \\
\hline $\begin{array}{l}\text { Died before survey } \\
\text { Terminated - working out }\end{array}$ & 一 & & - & 一 & 一 & 0 & - & $\mathbf{I}$ & - & $\mathbf{I}$ & 3 & 一 & 5 \\
\hline $\begin{array}{l}\text { of town } \\
\text { Unavailable- }\end{array}$ & 4 & 2 & - & - & 一 & 6 & 一 & 28 & 5 & - & - & - & 33 \\
\hline tal or away on vacation & 一 & 一 & $\mathbf{I}$ & 2 & 一 & 3 & 一 & 一 & $\mathbf{I}$ & 一 & $\mathbf{I}$ & $\mathbf{I}$ & 3 \\
\hline Missed-cause unknown .. & - & - & 一 & - & $\mathbf{I}$ & $\mathbf{I}$ & 一 & 一 & 一 & - & 一 & 一 & ० \\
\hline $\begin{array}{ccc}\text { Sample studied Dec. } 1963 / \\
\text { Jan. } 1964 & \ldots & \ldots\end{array}$ & 10 & 40 & 38 & 52 & 7 & 147 & - & 24 & 31 & 36 & $3 I$ & 2 & 124 \\
\hline Refusals & - & - & 一 & - & 2 & 2 & 一 & - & 一 & - & 2 & 一 & 2 \\
\hline
\end{tabular}


1932). Such studies suggest that it would be impossible to assign an average exposure to sulphur dioxide or other gases. The results of three airsampling surveys for $\mathrm{SO}_{2}$ are given in Table II, and average values for the gases are presented in Table
III. The higher values for $\mathrm{SO}_{2}$ were obtained in the sulphite plant. Sampling for hydrogen sulphide in the pulp mill did not reveal concentrations greater than the minimum detection sensitivity of the detector or 5 p.p.m.

TABLE II

Air Concentrations of Sulphur Dioxide (P.P.M.) at Various Work Stations in a Pulp Mill

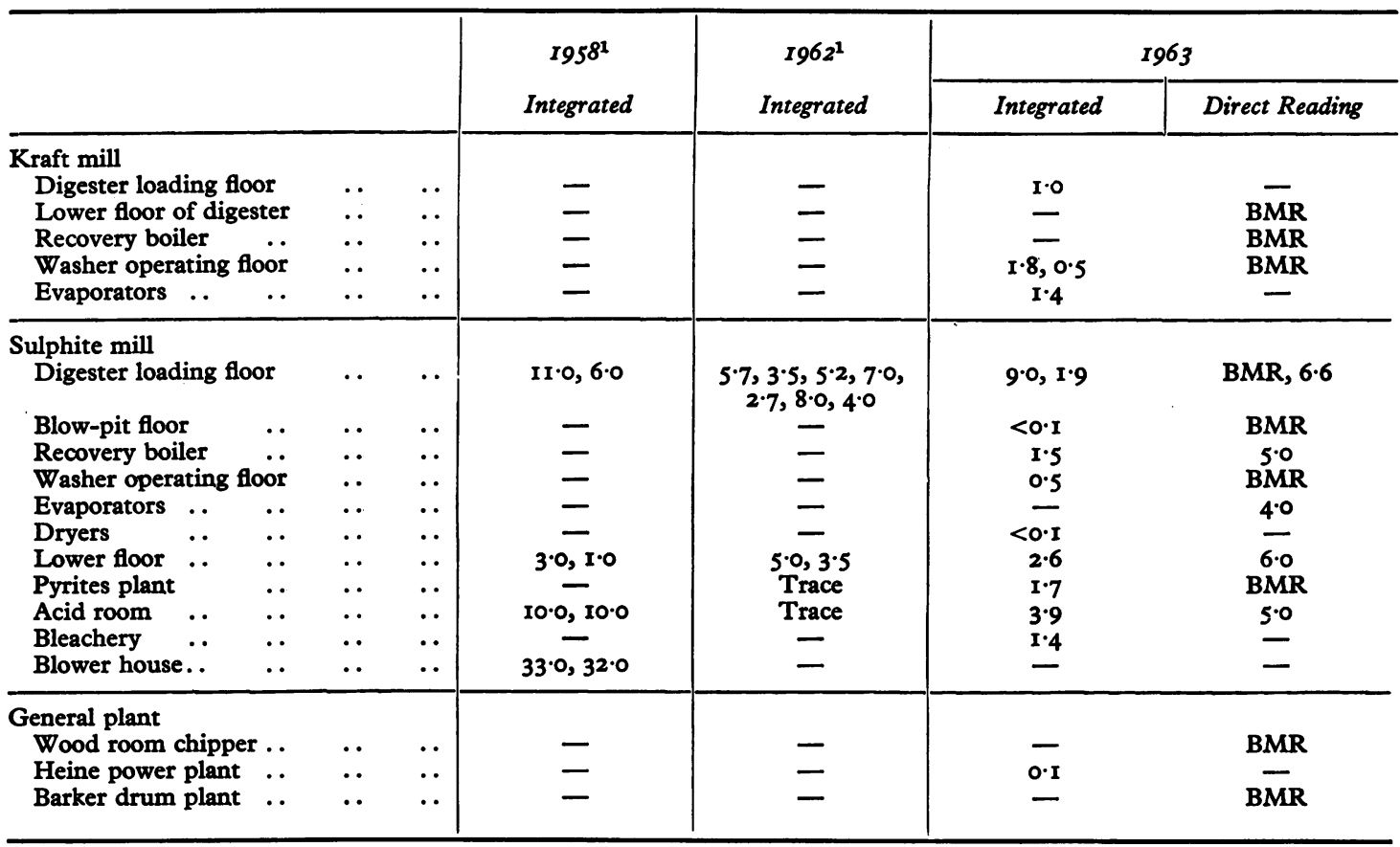

$\mathrm{BMR}=$ Below minimum reading, i.e., < 4.0 p.p.m.

${ }^{1}$ Data of comparable accuracy from insurance company.

TABLE III

Mran and Range of Concentration (P.P.m.) of Selected Gases in a Pulp Mill

\begin{tabular}{|c|c|c|c|c|c|c|c|c|c|c|c|}
\hline & \multirow{2}{*}{ Gas } & & \multicolumn{3}{|c|}{ 2I April I9581 } & \multicolumn{3}{|c|}{29 Fanuary $I 962^{1}$} & \multicolumn{3}{|c|}{ 7-8 February 1963} \\
\hline & & & No. & Mean & Range & No. & Mean & Range & No. & Mean & Range \\
\hline $\mathrm{ClO}_{2}$ & $\cdots$ & $\cdots$ & $\begin{array}{l}9 \\
9\end{array}$ & $\begin{array}{l}0.25 \\
0.011\end{array}$ & $\begin{array}{l}2 \cdot 0-0 \\
0 \cdot 02-0\end{array}$ & $\begin{array}{l}4 \\
3\end{array}$ & $\stackrel{0}{\text { Trace }}$ & $\begin{array}{l}0 \\
\text { Trace-o }\end{array}$ & - & - & $\longrightarrow$ \\
\hline $\mathrm{Cl}_{2}$ & $\cdots$ & $\cdots$ & $\begin{array}{l}9 \\
0\end{array}$ & $\begin{array}{l}7 \cdot 378 \\
0 \cdot 089\end{array}$ & $\begin{array}{l}64-0 \\
0 \cdot 3-0\end{array}$ & $\begin{array}{l}4 \\
3\end{array}$ & $\begin{array}{l}\text { Trace } \\
\text { Trace }\end{array}$ & $\begin{array}{l}\text { Trace } \\
\text { Trace }\end{array}$ & 8 & $\begin{array}{l}<0.001 \\
-\end{array}$ & Trace-o \\
\hline $\mathrm{SO}_{2}$ & $\cdots$ & $\cdots$ & 8 & 13.2 & 33-I & II & 4.05 & $\begin{array}{c}\text { 8.0-Trace } \\
-\end{array}$ & $\begin{array}{l}16 \\
17\end{array}$ & $\begin{array}{l}I \cdot 71 \\
2 \cdot 06\end{array}$ & $\begin{array}{l}3 \cdot 9-0 \\
6 \cdot 5-0\end{array}$ \\
\hline $\mathbf{H}_{2} \mathbf{S}$ & $\cdots$ & $\cdots$ & - & - & 一 & 6 & 0 & 0 & 7 & $<4$ & $<4$ \\
\hline
\end{tabular}

${ }^{1}$ Data from insurance company. 
The results of the three aerometric (industrial hygiene) surveys (Table II) show fairly consistent levels over the five years. The highest recorded values occurred in 1958. Higher levels had probably existed in the past but there were no records of comparable surveys. It is also possible that occasionally higher values occurred during this time span since even these three series represent a very limited sample.

The numbers of persons in various work categories at the time the populations were drawn are shown in Table IV. Of those surveyed, most had been in the same job category for many years. Table V summarizes the exposure history of these two groups to $\mathrm{SO}_{2}$ and $\mathrm{Cl}_{2}$. The exposures were determined from the work histories and a knowledge of the possible exposure in the various job categories.

The prevalence of chronic non-specific respiratory disease is presented by age group in Table VIa for the pulp and chemical mill and in Table VIb for the paper mill. Although slight differences exist, there is no statistically significant difference between the proportions with disease in the two mills. No correction has been applied for co-existing heart disease because those with heart disease did not fall into the category of obstructive lung disease where the presence of shortness of breath due to cardiac disease could have wrongly classified them.

TABLE IV

Number of Persons in Various Job Catrgories at Time Sample Drawn

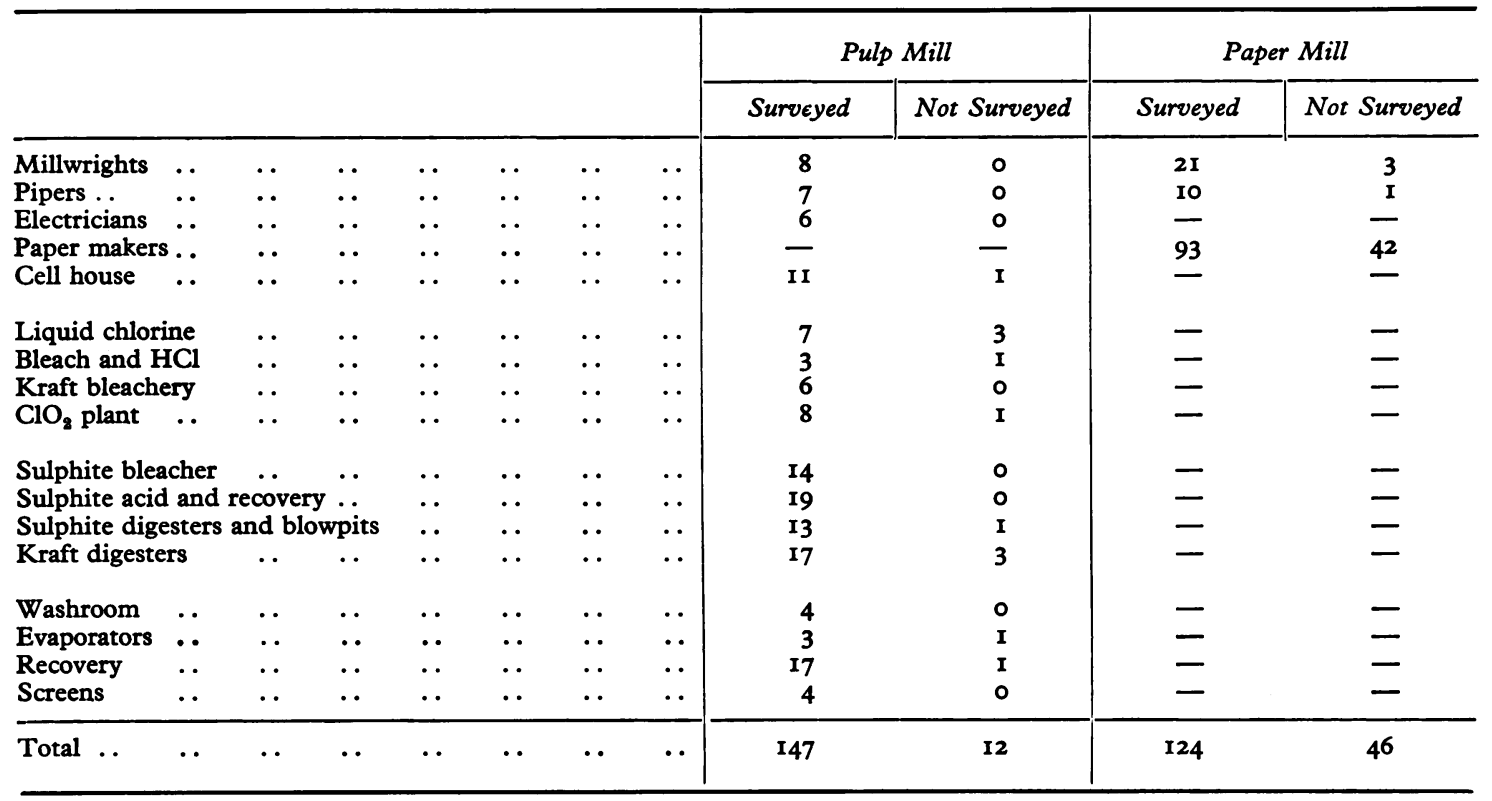

TABLE V

YeArs EXPosed to Gas

\begin{tabular}{|c|c|c|c|c|}
\hline & & $\mathrm{SO}_{2}$ & $\mathrm{Cl}_{2}$ & Total \\
\hline Pulp mill & $\begin{array}{l}\text { Average exposure (years) } \\
\text { S.D. } \\
\text { No. of subjects }\end{array}$ & $\begin{array}{r}16 \cdot 3 \\
\pm 13 \cdot 3 \\
118\end{array}$ & $\begin{array}{l}20 \cdot 4 \\
\pm 10 \cdot 67 \\
73\end{array}$ & $\frac{23 \cdot 2}{147}$ \\
\hline Paper mill & $\begin{array}{l}\text { Average exposure (years) } \\
\text { S.D. } \\
\text { No. of subjects }\end{array}$ & $\begin{array}{r}6.03 \\
\pm 5.99 \\
68\end{array}$ & $\begin{array}{c}7 \cdot 5 \\
+8 \cdot 66 \\
9\end{array}$ & $\frac{3 \cdot 85}{124}$ \\
\hline
\end{tabular}


TABLE VIa

Prevalence of Chronic Non-specific Respiratory Diseases in Pulp Mill, 1963

\begin{tabular}{|c|c|c|c|c|c|c|c|}
\hline \multicolumn{2}{|c|}{$\begin{array}{l}\text { Age Group } \\
\text { (years) }\end{array}$} & $\begin{array}{c}\text { No } \\
\text { Disease }\end{array}$ & $\begin{array}{c}\text { Chronic } \\
\text { Bronchitis }\end{array}$ & $\begin{array}{l}\text { Obstructive } \\
\text { Lung Disease } \\
\text { (O.L.D.) }\end{array}$ & $\begin{array}{l}\text { Chronic } \\
\text { Bronchitis } \\
+ \text { O.L.D. }\end{array}$ & $\begin{array}{c}\text { Chronic } \\
\text { Bronchitis, + } \\
\text { O.L.D. + Asthma }\end{array}$ & Total \\
\hline $\begin{array}{l}25-34 \\
35-44 \\
45-54 \\
55-64 \\
65-74\end{array}$ & $\begin{array}{l}. . \\
. \\
. \\
.\end{array}$ & $\begin{array}{r}8(80 \cdot 0) \\
29(72 \cdot 5) \\
24(63 \cdot 0) \\
34(65 \cdot 5) \\
4(57 \cdot 2)\end{array}$ & $\begin{array}{r}1(10.0) \\
7(17.5) \\
7(18.4) \\
13(25.0) \\
1(14.3)\end{array}$ & $\begin{array}{lr}1 & (10.0) \\
1 & (2.5) \\
4 & (10.5) \\
1 & (1.9) \\
0 & \end{array}$ & $\begin{array}{lc} & - \\
3 & (7.5) \\
3 & (7.9) \\
3 & (5.8) \\
2 & (28.6)\end{array}$ & $\begin{array}{l}\overline{-} \\
\overline{(I \cdot 9)}\end{array}$ & $\begin{array}{r}10 \\
40 \\
38 \\
52 \\
7\end{array}$ \\
\hline Total & .. & $99(67 \cdot 5)$ & $29(19.7)$ & $7(4 \cdot 8)$ & II $(7 \cdot 5)$ & I $(0.7)$ & 147 \\
\hline
\end{tabular}

Figures in parentheses are percentage prevalences.

TABLE VIb

Prevalence of Chronic Non-Specific Respiratory Diseases in Paper Mill, 1963

\begin{tabular}{|c|c|c|c|c|c|c|c|}
\hline $\begin{array}{c}\text { Age Group } \\
\text { (years) }\end{array}$ & $\begin{array}{c}\text { No } \\
\text { Disease }\end{array}$ & $\begin{array}{l}\text { Chronic } \\
\text { Bronchitis }\end{array}$ & $\begin{array}{c}\text { Obstructive } \\
\text { Lung Disease } \\
\text { (O.L.D.) }\end{array}$ & $\begin{array}{l}\text { Chronic } \\
\text { Bronchitis } \\
+ \text { Asthma }\end{array}$ & $\begin{array}{c}\text { Chronic } \\
\text { Bronchitis } \\
+ \text { O.L.D. }\end{array}$ & $\begin{array}{c}\text { Chronic } \\
\text { Bronchitis, + } \\
\text { O.L.D. + } \\
\text { Asthma }\end{array}$ & Total \\
\hline $\begin{array}{l}25-34 \\
35-44 \\
45-54 \\
55-64 \\
65-74\end{array}$ & $\begin{array}{r}14(58.4) \\
26(84.0) \\
29(80 \cdot 0) \\
20(64.5) \\
1(50 \cdot 0)\end{array}$ & $\begin{array}{l}8(33 \cdot 3) \\
5(16.0) \\
5(13.9) \\
7(22.6) \\
1(50.0)\end{array}$ & $\begin{array}{c}I(4 \cdot 2) \\
I \overline{(3 \cdot 2)}\end{array}$ & $\begin{array}{l}- \\
I(2 \cdot 7) \\
I(3 \cdot 2) \\
-\end{array}$ & $\begin{array}{l}I(4 \cdot 2) \\
\text { I }(2 \cdot 7) \\
I(3 \cdot 2) \\
\end{array}$ & $\frac{\bar{Z}}{\overline{(3 \cdot 2)}}$ & $\begin{array}{r}24 \\
31 \\
36 \\
31 \\
2\end{array}$ \\
\hline Total & $90(72 \cdot 6)$ & $26(20.9)$ & $2(1 \cdot 6)$ & $2(1 \cdot 6)$ & $3(2 \cdot 4)$ & $1(0.8)$ & 124 \\
\hline
\end{tabular}

Figures in parentheses are percentage prevalences.

Expected rates of diseases were calculated from the rates of the two mill populations pooled for the various categories of age and current pipe, cigar or cigarette smoking habits. The rates for each group were summed, and the over-all expected rates of respiratory disease were then compared with the observed to determine whether there was any significant difference. In each instance no significant difference was observed between the two mills.

In order to examine the effect of tobacco usage on chronic non-specific respiratory disease, agestandardized rates were calculated as in Table VII.

Asthma did not occur as a separate entity and therefore no rates have been calculated for this disease. The number of men with obstructive lung disease was too small to allow reliable rates to be calculated for this category. These can be estimated as the difference between chronic bronchitis alone and chronic bronchitis with other respiratory disease, since asthma was relatively uncommon, as indicated in Tables VIa and VIb. The rates have been obtained by indirect standardization, by using the male age-specific rates, all smoking categories together, from the sample from Berlin, N.H. (Table III, Ferris and Anderson, 1962) as the standard rates. Each age-specific rate was applied to the number of persons in the corresponding age group within each smoking category to provide an expected number of diseased persons. The numbers for all age groups were added within each smoking category to obtain the total expected number for that category. The indirect age-standardized rate was then obtained from the relationship:-

Age-standardized rate for smoking category = Observed Crude rate for all smoking categories Expected $\times$ together from Berlin, N.H. (Ferris and Anderson, 1962)

In Table VIII age-standardized rates of chronic non-specific respiratory disease are presented by current cigarette consumption. They were calculated in the same way as those in Table VII.

Prediction formulae based on age and height for F.V.C., F.E.V.1.0, and peak expiratory flow rate (P.E.F.R.) were calculated for those men who 


\section{TABLE VII}

Age-standardized Rates of Chronic Non-specific Respiratory Disease by Current Tobacco Product Smoked and by PLACE OF WORK, 1963 (IN PERCENTAGE)

\begin{tabular}{|c|c|c|c|c|c|c|c|c|c|c|c|}
\hline \multirow{2}{*}{\multicolumn{4}{|c|}{ Current Tobacco Usage }} & \multicolumn{2}{|c|}{ No. of Subjects } & \multicolumn{2}{|c|}{$\begin{array}{l}\text { All Chronic Non- } \\
\text { specific Respiratory } \\
\text { Disease }\end{array}$} & \multicolumn{2}{|c|}{$\begin{array}{c}\text { Chronic Bronchitis } \\
\text { and Other Respiratory } \\
\text { Disease }\end{array}$} & \multicolumn{2}{|c|}{$\begin{array}{c}\text { Chronic Bronchitis } \\
\text { Alone }\end{array}$} \\
\hline & & & & Pulp & Paper & Pulp & Paper & Pulp & Paper & Pulp & Paper \\
\hline Never & .. & .. & . & 10 & II & $\begin{array}{l}\text { I0.0 } \\
\text { (I) }\end{array}$ & $\begin{array}{l}10.5 \\
\text { (I) }\end{array}$ & $\begin{array}{l}9 \cdot 3 \\
(1)\end{array}$ & $\begin{array}{l}9 \cdot 0 \\
\text { (I) }\end{array}$ & $\begin{array}{l}6.6 \\
\text { (I) }\end{array}$ & $\begin{array}{l}6.6 \\
\text { (I) }\end{array}$ \\
\hline Ex-smoker & .. & .. & .. & 25 & 22 & $\begin{array}{l}15.1 \\
\text { (4) }\end{array}$ & $\begin{array}{l}21 \cdot 7 \\
(5)\end{array}$ & $\begin{array}{l}8 \cdot 0 \\
\text { (2) }\end{array}$ & $\begin{array}{l}22 \cdot 5 \\
(5)\end{array}$ & $\begin{array}{l}8 \cdot 3 \\
\text { (2) }\end{array}$ & $\begin{array}{l}12 \cdot 4 \\
\text { (3) }\end{array}$ \\
\hline Pipe and/or & r cigar & .. & .. & 14 & 6 & $\begin{array}{l}0 \\
\text { (o) }\end{array}$ & $\begin{array}{l}0 \\
\text { (0) }\end{array}$ & $\begin{array}{l}0 \\
\text { (o) }\end{array}$ & $\begin{array}{l}0 \\
\text { (o) }\end{array}$ & $\begin{array}{l}0 \\
\text { (o) }\end{array}$ & $\begin{array}{l}0 \\
\text { (o) }\end{array}$ \\
\hline Cigarette & .. & .. & .. & 79 & 66 & $\begin{array}{l}47 \cdot 4 \\
(38)\end{array}$ & $\begin{array}{l}36 \cdot 2 \\
(22)\end{array}$ & $\begin{array}{l}40 \cdot 7 \\
(33)\end{array}$ & $\begin{array}{l}27.2 \\
\text { (I9) }\end{array}$ & $\begin{array}{l}24 \cdot 7 \\
(24)\end{array}$ & $\begin{array}{l}16.7 \\
\text { (17) }\end{array}$ \\
\hline Mixed & .. & .. & .. & 19 & 19 & $\begin{array}{l}26 \cdot 0 \\
(5)\end{array}$ & $\begin{array}{l}3 \mathrm{I} \cdot 6 \\
(6)\end{array}$ & $\begin{array}{l}25.6 \\
(5)\end{array}$ & $\begin{array}{l}30 \cdot 9 \\
(6)\end{array}$ & $\begin{array}{l}8 \cdot 3 \\
(2)\end{array}$ & $\begin{array}{l}2 \mathrm{I} \cdot \mathrm{I} \\
(5)\end{array}$ \\
\hline Total & .. & .. & .. & $\mathbf{1 4 7}$ & 124 & $\begin{array}{l}48 \cdot 3 \\
(48)\end{array}$ & $\begin{array}{l}39 \cdot 7 \\
(34)\end{array}$ & $\begin{array}{l}39 \cdot 1 \\
(40)\end{array}$ & $\begin{array}{r}32 \cdot 9 \\
(3 I)\end{array}$ & $\begin{array}{l}22 \cdot 8 \\
(29)\end{array}$ & $\begin{array}{l}20 \cdot 2 \\
(26)\end{array}$ \\
\hline
\end{tabular}

Figures in parentheses are numbers in each cell.

TABLE VIII

Age-standardized Rates of Chronic Non-specific Respiratory Disease by Current Cigarette Smoking Category and BY PLACE OF WORK, I963 (IN PERCENTAGE)

\begin{tabular}{|c|c|c|c|c|c|c|c|c|c|c|c|}
\hline \multicolumn{4}{|c|}{$\begin{array}{c}\text { Current Cigarette Smoking } \\
\text { Category }\end{array}$} & \multicolumn{2}{|c|}{ No. of Subjects } & \multicolumn{2}{|c|}{$\begin{array}{l}\text { All Chronic Non- } \\
\text { specific Respiratory } \\
\text { Disease }\end{array}$} & \multicolumn{2}{|c|}{$\begin{array}{c}\text { Chronic Bronchitis } \\
\text { with Other Respiratory } \\
\text { Disease }\end{array}$} & \multicolumn{2}{|c|}{$\begin{array}{l}\text { Chronic Bronchitis } \\
\text { Alone }\end{array}$} \\
\hline & & & & Pulp & Paper & Pulp & Paper & Pulp & Paper & Pulp & Paper \\
\hline Nil .. & .. & .. &.. & 49 & 39 & IO.I & $\begin{array}{l}15.8 \\
(6)\end{array}$ & $6 \cdot 0$ & $\begin{array}{l}15 \cdot 1 \\
(6)\end{array}$ & $5 \cdot 0$ & $8 \cdot 3$ \\
\hline$I-4 \quad \cdots$ & .. & .. &.. & 4 & 5 & $\begin{array}{l}0.0 \\
(0)\end{array}$ & $\begin{array}{l}20 \cdot 6 \\
(\mathrm{I})\end{array}$ & $\begin{array}{l}0.0 \\
(0)\end{array}$ & $\begin{array}{l}18 \cdot 7 \\
(I)\end{array}$ & $\begin{array}{l}0 \cdot 0 \\
(0)\end{array}$ & $\begin{array}{l}12 \cdot 7 \\
(\mathrm{I})\end{array}$ \\
\hline $5-14 \ldots$ & .. & .. & .. & 9 & 15 & $\begin{array}{l}47.0 \\
(4)\end{array}$ & $\begin{array}{l}19 \cdot 0 \\
(3)\end{array}$ & $\begin{array}{l}32 \cdot 2 \\
(3)\end{array}$ & $\begin{array}{l}13 \cdot 1 \\
(2)\end{array}$ & $\begin{array}{l}\text { I0.8 } \\
(2)\end{array}$ & $\begin{array}{l}\text { II.8 } \\
(2)\end{array}$ \\
\hline $15-24$ & .. & .. & .. & 49 & 36 & $\begin{array}{l}39 \cdot 7 \\
(20)\end{array}$ & $\begin{array}{l}36 \cdot 3 \\
(12)\end{array}$ & $\begin{array}{l}33 \cdot 8 \\
(17)\end{array}$ & $\begin{array}{l}26 \cdot 5 \\
(10)\end{array}$ & $\begin{array}{l}19 \cdot 9 \\
\text { (I2) }\end{array}$ & $\begin{array}{l}14 \cdot 8 \\
(8)\end{array}$ \\
\hline 2534 & .. & .. &.. & 20 & 15 & $\begin{array}{l}49 \cdot 0 \\
\text { (10) }\end{array}$ & $\begin{array}{l}21 \cdot 9 \\
(3)\end{array}$ & $\begin{array}{l}38 \cdot 9 \\
(8)\end{array}$ & $\begin{array}{l}18 \cdot 7 \\
(3)\end{array}$ & $\begin{array}{l}29 \cdot 3 \\
(7)\end{array}$ & $\begin{array}{l}12 \cdot 7 \\
(3)\end{array}$ \\
\hline $35+\ldots$ & .. & .. & .. & 16 & 14 & $\begin{array}{l}57 \cdot 8 \\
(9)\end{array}$ & $\begin{array}{c}73 \cdot 2 \\
(9)\end{array}$ & $\begin{array}{l}54 \cdot I \\
(9)\end{array}$ & $\begin{array}{l}60 \cdot 2 \\
(9)\end{array}$ & $\begin{array}{l}24.0 \\
(5)\end{array}$ & $\begin{array}{l}34.9 \\
(8)\end{array}$ \\
\hline Total & .. & .. & .. & I 47 & 124 & $\begin{array}{l}48 \cdot 3 \\
(48)\end{array}$ & $\begin{array}{l}39 \cdot 7 \\
(34)\end{array}$ & $\begin{array}{l}39 \cdot 1 \\
(40)\end{array}$ & $\begin{array}{l}32 \cdot 9 \\
(3 I)\end{array}$ & $\begin{array}{l}22 \cdot 8 \\
(29)\end{array}$ & $\begin{array}{l}20 \cdot 2 \\
(26)\end{array}$ \\
\hline
\end{tabular}

Figures in parentheses are numbers in each cell.

worked in the pulp mill, for those who worked in the paper mill, and for the total group. An analysis of variance for testing the equality of regression coefficients (including the constant term) (Rao, 1952) was done on the two equations for each group. No significant difference was demonstrated.

\section{Discussion}

When we planned this study we thought that the men in the paper mill would be a good control population to compare with the men from the pulp mill. As the survey progressed, it became apparent 
that considerable self-selection had taken place. When they started with the company most of the men worked in the general labour pool and usually worked in or around the pulp mill. Many of the men who transferred to the paper mill did so because they did not like the odours in and around the pulp mill. Wage scales were slightly higher on the paper machines so this also could have been a reason for changing to the paper mill. The men who worked in the paper mill may represent a group with respiratory tracts more sensitive to irritant gases than the men who remained in the pulp mill.

An examination of Tables VIa and VIb reveals some difference in the rates of respiratory diseases as diagnosed by responses to the questionnaire. If the total number with disease, however, is compared in a four-fold table no significant difference can be demonstrated between the two mills. If the total mill population with and without disease is compared in a similar manner with those with and without disease (after removing those with heart disease) from the Berlin survey (Ferris and Anderson, 1962), where the rates were slightly higher, there is a significant difference $(0.01<\mathrm{P}<0.05)$. There is, therefore, significantly less respiratory disease in the total mill population than in the general male population of the town.

An analysis (not presented here) of specific questions showed a slightly higher prevalence of positive answers in the pulp mill, but not so high as that reported by Skalpe (1964). The difference could be attributed to the higher percentage of smokers in Skalpe's population or to different criteria. Direct comparisons are difficult, but the trend is similar to Skalpe's. In contrast, Anderson (1950) reported no difference between exposed and non-exposed workers. Kehoe and his colleagues (1932) studied men in a refrigerator plant who were exposed to $\mathrm{SO}_{2}(20$ to 30 p.p.m. with peaks of 55 to 70 p.p.m.); their control group was exposed to CO. They noted a greater prevalence of respiratory symptoms in the exposed group. Chest radiographs in Kehoe's series showed the same distribution of abnormalities. Kehoe and his colleagues concluded, however, that there was no evidence of injury to the lungs. On the other hand, the exposed group had greater fatiguability and more shortness of breath on exertion. No correction was made in that study for possible differences in smoking habits.

The age-standardized rates of chronic nonspecific respiratory disease in our study, calculated from the male population of Berlin as the standard, show lower rates for respiratory disease by current tobacco usage and by current cigarette smoking than in the town as a whole. This demonstrates

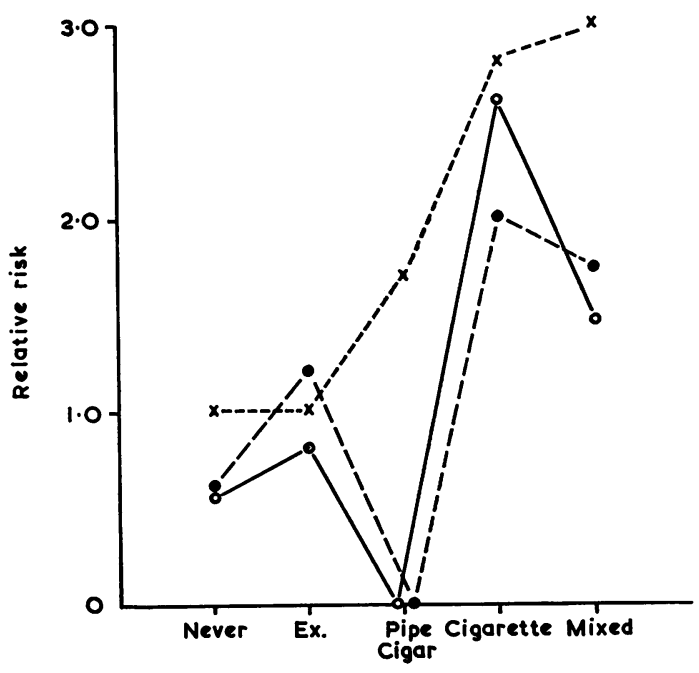

FIG. 3. Relative risk of developing chronic non-specific respiratory disease (all types) by current tobacco usage. [ $\bigcirc$ pulp; $\odot$ paper; $\times$ Berlin.]

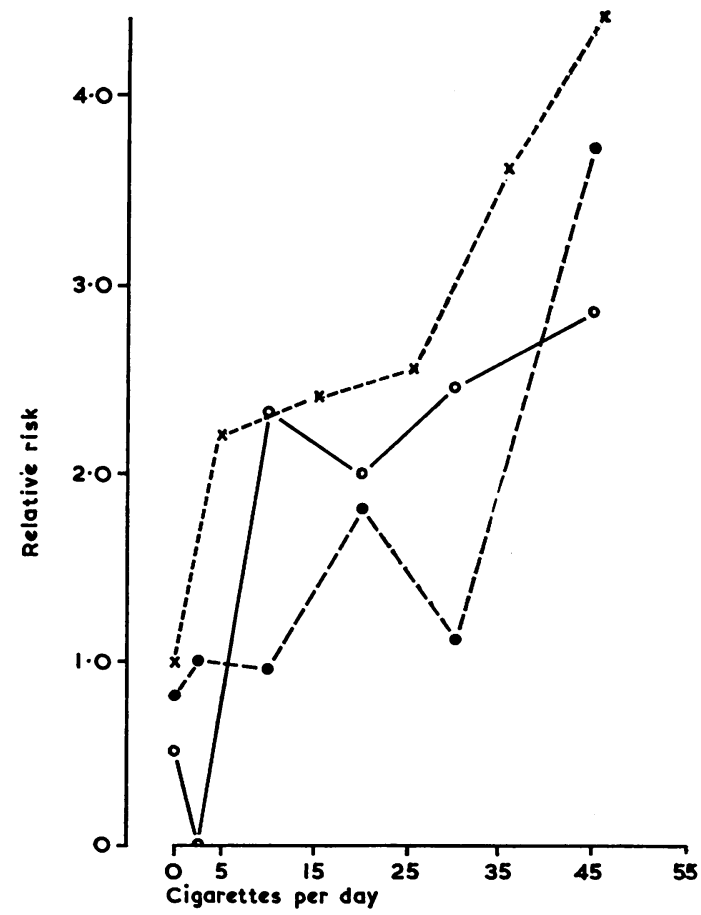

FIG. 4. Relative risk of developing chronic non-specific respiratory disease by current cigarette smoking. [ $O$ pulp; $\odot$ paper; $\times$ Berlin.] 
that working populations are not representative samples of a general population.

These standardized prevalence rates can be expressed as a relative risk of developing disease as shown in Figs. 3 and 4 for the two mills. The relative risk of unity was taken as the disease rate of males who never smoked cigarettes or non-smokers of cigarettes from the Berlin study (Anderson and Ferris, 1962). The cigarette smokers in the pulp mill had a higher relative risk than those in the paper mill. Male cigarette smokers from the town had the greatest risk. The low risk in pipe and/or cigar smokers probably reflects the small number of persons in these categories. When the relative risk by current cigarette consumption is examined, the pulp mill shows higher rates for the moderately heavy smokers. In both mills there is a general trend of increasing risk of disease with increase in daily cigarette consumption. This increase, however, is not as large as that seen in the Berlin male population.

The results of selected measurements of pulmonary function are presented in Table IX and compared with similar results presented by Skalpe (1964). Skalpe's exposed group under 50 years had low peak flows, whereas the Berlin group did not show such a difference. In fact, millwrights in the paper mill had low peak flow values and paper-mill pipers had the lowest forced vital capacities; pipers over 50 had the lowest peak flows. Some of the decrease in the values in the older age groups may be due to their shorter heights.

Because the pulp mill population was composed of two groups, one exposed largely to $\mathrm{SO}_{2}$ and the other to $\mathrm{Cl}_{2}$ or $\mathrm{ClO}_{2}$, we decided to see whether differences existed between them. In Table IX no differences were noted for simple tests of pulmonary function. If we examine the prevalence of positive responses to selected questions for men exposed to $\mathrm{SO}_{2}$ or $\mathrm{Cl}_{2}$ or $\mathrm{ClO}_{2}$ (Table $\mathrm{X}$ ) some differences can be seen. In only three instances do these differences reach a statistically significant level. Others demonstrate a trend that indicates that exposure to $\mathrm{Cl}_{2}$ or $\mathrm{ClO}_{2}$ are more serious than exposures to $\mathrm{SO}_{2}$. More of the men who worked in $\mathrm{SO}_{2}$ were cigarette smokers and this should weigh these data against finding an effect of exposure to chlorine. When the prevalence of positive response was compared with that from the paper mill, the rates for the men working in chlorine were higher and those for the men in $\mathrm{SO}_{2}$ slightly lower. Thus the pooled data from the pulp mill workers were, in general, similar to those from the paper mill.

Further evidence of the deleterious effect of $\mathrm{Cl}_{2}$ is shown in Fig. 5 where volume-flow plots are presented for cigarette smokers of various age groups working with paper, $\mathrm{SO}_{2}$, and $\mathrm{Cl}_{2}$. These were obtained by measuring the slope of the last

TABLE IX

Pulmonary Function in Men in Pulp Mills and in Paper Mills

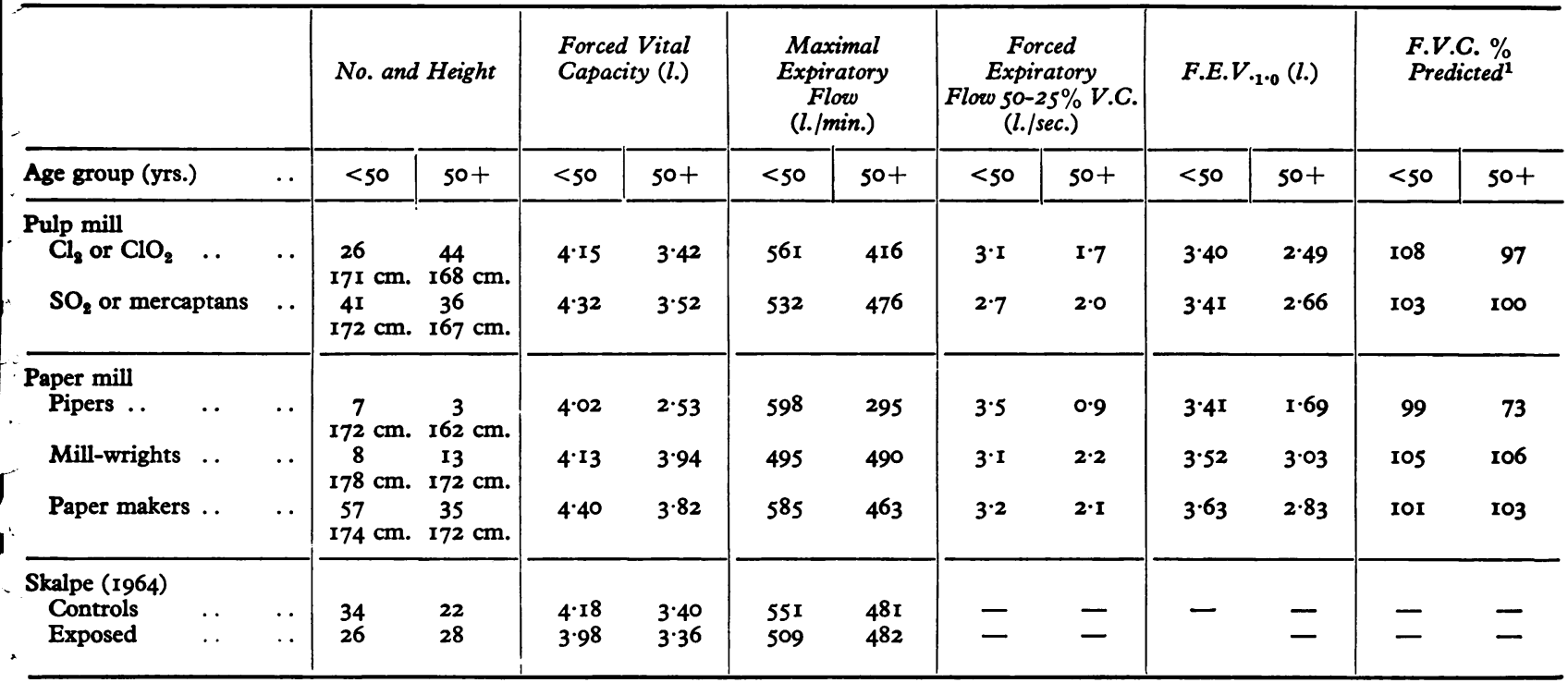

$\because \quad$ Based on Berlin, N.H. population. 


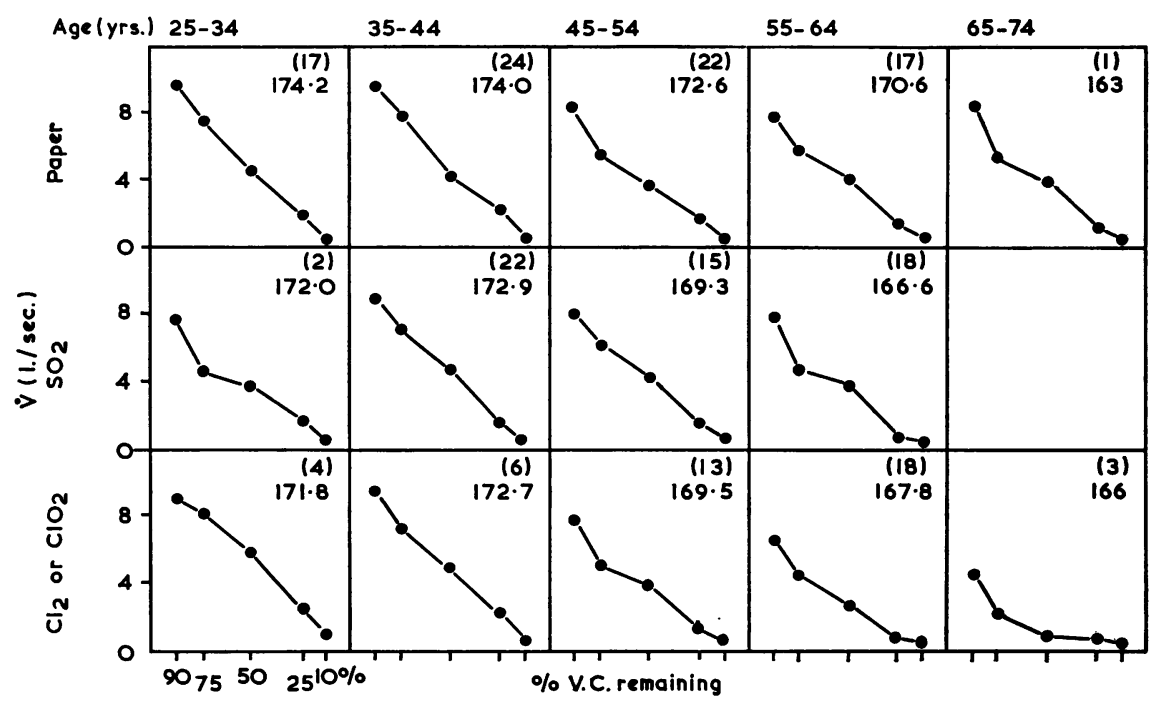

FIG. 5. Volume-flow curves in pulp and paper mill workers by age groups-cigarette smokers only.

[The figures inside the squares represent the number of subjects (in parentheses) and their average height in centimetres.]

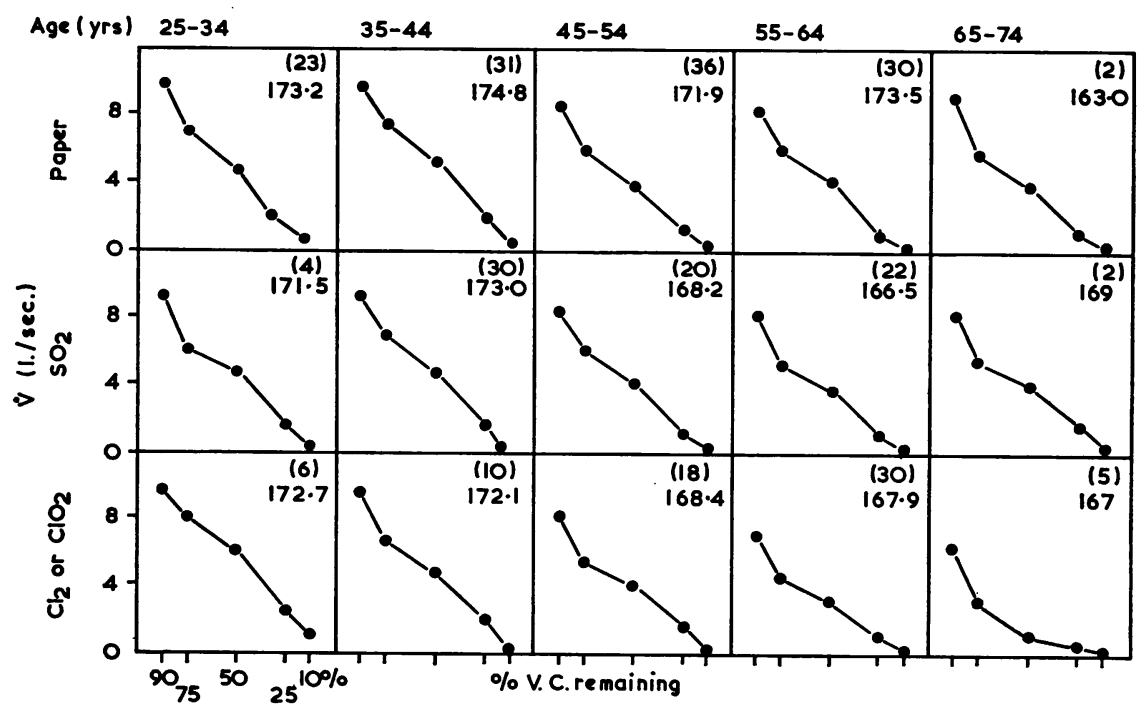

FIG. 6. Volume-flow curves in pulp and paper mill workers by age groups. 
TABLE X

Prevalence of Positive Responses to Selected Questions from Men Exposed to $\mathrm{SO}_{2}$ or $\mathrm{Cl}_{2}$ In PUlp Mill

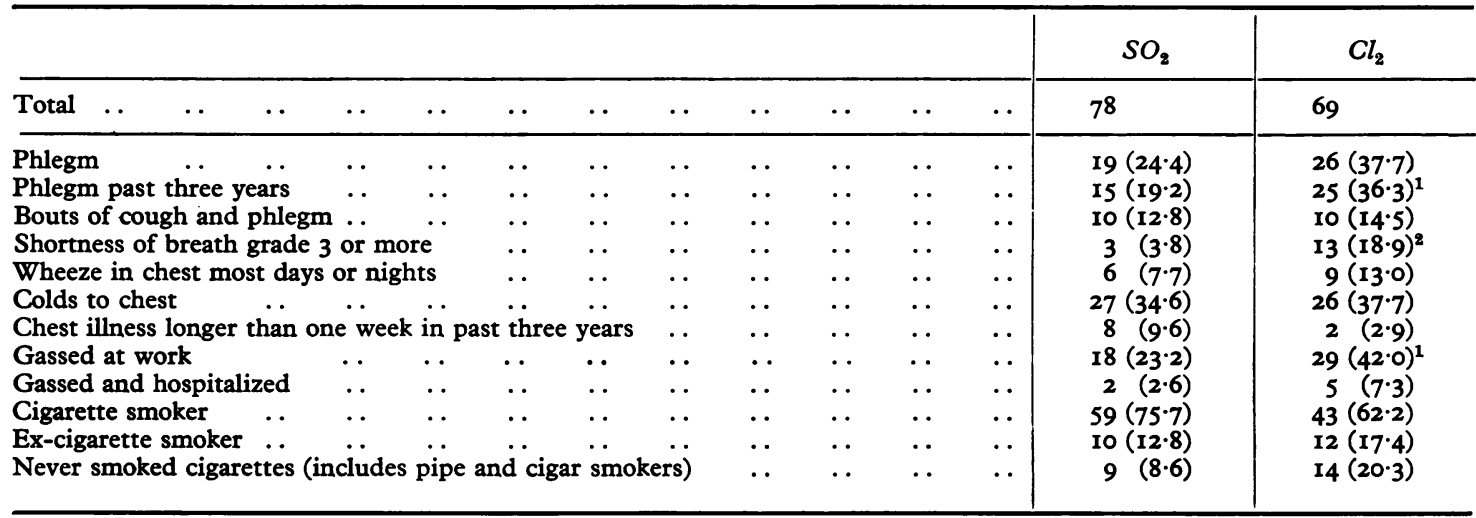

Figures in parentheses are percentages.

1Significant difference $0.10<P<0.05$.

${ }^{2}$ Highly significant difference $P<0.01$.

three F.V.C. curves at the specified lung volumes from the tracing obtained on a Stead-Wells spirometer with a fast paper speed and averaging them. The error in lung volume associated with the compression of the gas in the lungs has been ignored, and, as a result, the flows are plotted at higher lung volumes than probably actually existed. This error also will vary depending on the amount of effort expended by the subject: the greater the effort, the greater the error. The value at $90 \%$ of vital capacity was taken to be the maximal expiratory flow rate. The men exposed to $\mathrm{Cl}_{2}$ show a more rapid decrease with age in all aspects of their volumeflow plots than do the men exposed to $\mathrm{SO}_{2}$ or those who are paper workers. The differences are not statistically significant, even in the older age groups where there are obvious differences, due to the small numbers. If the results from all the workers in these categories are plotted, similar trends are seen but not as pronounced as in the cigarette smokers (Fig. 6).

The authors gratefully acknowledge the co-operation of the Brown Company, Berlin, N.H., and of the workers in the two mills who made this study possible.

\section{REFERENCES}

American College of Chest Physicians (1963). Dis. Chest, 43, 214.

Anderson, A. (1950). Brit. F. industr. Med., 7, 82.

Anderson, D. O., and Ferris, B. G., Jr. (1962). New Engl. $\mathcal{F}$. Med., 267, 787.

Ferris, B. G., Jr., and Anderson, D. O. (1962). Amer. Rev. resp. Dis., 86, 165.

Kehoe, R. A., Machle, W. F., Kitzmiller, K., and LeBlanc, T. J. (1932). F. industr. Hyg., $14,159$.

Rao, C. R. (1952). Advanced Statistical Methods in Biometric Research, p. I12. John Wiley, New York.

Skalpe, I. O. (1964). Brit. F. industr. Med., 21, 69. 